\title{
Effect of protein malnutrition on the glycolytic and glutaminolytic enzyme activity of rat thymus and mesenteric lymph nodes
}

\author{
M.A. dos-Santos ${ }^{1,2}$, \\ R. Rosa ${ }^{1}$, \\ R. Curi ${ }^{2}$ and \\ D.H.G.P. Barbieri ${ }^{1}$
}

\author{
${ }^{1}$ Departamento de Análises Clínicas, Faculdade de Ciências Farmacêuticas, and \\ 2Departamento de Fisiologia e Biofísica, instituto de Ciências Biomédicas, \\ Universidade de São Paulo, 05508-900 São Paulo, SP, Brasil
}

\section{Correspondence}

M.A. dos-Santos

Departamento de Fisiologia

e Biofísica, ICB, USP

Av. Prof. Lineu Prestes, 1524

05508-900 São Paulo, SP

Brasil

Fax: 55 (011) 818-7285

E-mail: mabia@bmb.icb1.usp.br

Research supported by FAPESP CNPq and CAPES

This paper is dedicated to the late Prof. D.H.G.P. Barbieri.

Received August 15, 1996 Accepted March 31, 1997

\begin{abstract}
The activity of important glycolytic enzymes (hexokinase, phosphofructokinase, aldolase, phosphohexoseisomerase, pyruvate kinase and lactate dehydrogenase) and glutaminolytic enzymes (phosphate-dependent glutaminase) was determined in the thymus and mesenteric lymph nodes of Wistar rats submitted to protein malnutrition $(6 \%$ protein in the diet rather than $20 \%$ ) from conception to 12 weeks after birth. The wet weight ( $\mathrm{g}$ ) of the thymus and mesenteric lymph nodes decreased due to protein malnutrition by $87 \%$ (from $0.30 \pm 0.05$ to $0.04 \pm 0.01)$ and $75 \%(0.40 \pm 0.04$ to $0.10 \pm 0.02)$, respectively. The protein content was reduced only in the thymus from $102.3 \pm 4.4$ (control rats) to $72.6 \pm 6.6$ (malnourished rats). The glycolytic enzymes were not affected by protein malnutrition, but the glutaminase activity of the thymus and lymph nodes was reduced by half in proteinmalnourished rats as compared to controls. This fact may lead to a decrease in the cellularity of the organ and thus in its size, weight and protein content.
\end{abstract}

It is widely accepted that protein-energy malnutrition (PEM) is associated with compromised immune function. Deficiencies in secretory $\operatorname{IgA}$, complement, phagocytic activity, and decreased lymphocyte proliferation in response to phytohemagglutinin stimulation have been reported to occur under these conditions (1). In 1991, Chandra (2) reviewed the impairment of immune function that occurs in PEM and correlated these changes with the incidence of infection and the high morbidity of children younger than 5 years in developing countries. A high inci- dence of pneumonia and diarrhea during the first 4 years of life has been reported by Victora et al. (3) in Brazilian children. Lymphoid atrophy is a prominent feature observed in humans and laboratory animals with PEM. Anatomical changes occurring in lymphoid tissues in malnutrition have been described for over 144 years. The thymus was noted to be "a barometer of malnutrition, and a very sensitive one" (2). The size and weight of the thymus are reduced. Histologically, there is a loss of corticomedullary differentiation and fewer lymphoid cells are 
observed. In the spleen there is a loss of lymphoid cells around small blood vessels. In lymph nodes the thymus-dependent paracortical areas show depletion of lymphocytes (2). In spite of the changes in the structure and function of the lymphoid organs, to our knowledge no systematic studies have been performed on the metabolism of these tissues in protein malnutrition.

Several studies have shown the important role played by lymphocyte metabolism for its proliferation (4). These cells utilize glucose and glutamine at high rates but these substrates are only partially oxidized: glucose is converted to lactate and glutamine to glutamate, aspartate and lactate $(5,6)$. Therefore, it has been recognized that the main metabolic pathways of these cells are glycolysis (partial oxidation of glucose) and glutaminolysis (partial oxidation of glutamine). In fact, these pathways provide ATP (7) and generate important precursors for the synthesis of macromolecules such as lipids (8) and nucleotides (5). Glycolysis is partially regulated by certain enzyme activities such as hexokinase (HK), phosphohexoseisomerase (PHI), phosphofructokinase-1 (PFK-1), aldolase, pyruvate kinase (PK) and lactate dehydrogenase (LDH) and glutami-

Table 1 - Composition of control and protein-deficient diets.

Diets were prepared as described in Ref. 9. ${ }^{\text {TT }}$ The values of $20 \%$ and $6 \%$ of protein were corrected by adding casein containing $85 \%$ total protein.

\begin{tabular}{lcc} 
& \multicolumn{2}{c}{ Composition (g/100 g) } \\
\cline { 2 - 3 } & Control diet & Protein-deficient diet \\
\hline Casein $^{\mathrm{a}}$ & 20 & 6 \\
Starch & 32.5 & 36.0 \\
Glucose & 9.0 & 15.0 \\
Sucrose & 22.6 & 27.4 \\
DL-Methionine & 0.5 & 0.2 \\
Corn oil & 10.0 & 10.0 \\
Salt mixture & 4.0 & 4.0 \\
Vitamin mixture & 1.0 & 1.0 \\
Choline hydrochloride & 0.4 & 0.4
\end{tabular}

nolysis is regulated by phosphate-dependent glutaminase. Knowing that glucose and glutamine are important metabolites for lymphocytes, the impaired immune function in malnourished rats could be caused by a decrease of the activity of these enzymes. In the present study, the activities of these enzymes were determined in the thymus and mesenteric lymph nodes of rats submitted to protein malnutrition from conception to 12 weeks after birth.

The rats received a control diet containing $20 \%$ protein (9) or a protein-deficient diet containing $6 \%$ protein (Table 1). Pregnant rats were maintained on the control or protein-deficient diet throughout pregnancy and until weaning. The average number of pups per mother was $8.1 \pm 0.7$ for control and $7.3 \pm 0.6$ for malnourished rats (means \pm SEM of 8 mothers). After weaning, male rats were fed ad libitum for 12 weeks with the same diet given to the mothers. A similar schedule to impose malnutrition has been used by others $(10,11)$. Daily food intake $(\mathrm{g} /$ $100 \mathrm{~g}$ body weight) at the end of this period was $6.3 \pm 0.6$ for control and $7.6 \pm 1.8$ for undernourished rats (means \pm SEM of 20 animals). These findings support the proposition that total calorie intake was appropriate for age/weight of the rats and therefore the protocol provides a model for protein malnutrition but with normal calorie intake.

The rats were kept in a room at $23 \pm 2^{\circ} \mathrm{C}$ on a 12-h dark/light cycle (lights on at 7:00 p.m.). All rats were killed by cervical dislocation without anesthesia and blood was collected for determination of total protein by the method of Gornall et al. (12). The lymphoid organs (thymus and mesenteric lymph nodes) were removed, weighed and kept in liquid nitrogen prior to the measurement of protein content and enzyme activities. All chemicals and enzymes were obtained from Sigma Chemical Co. (St. Louis, $\mathrm{MO})$.

On the basis of preliminary experiments carried out to provide optimal conditions for 
extraction, glycolytic enzymes were extracted with the following medium: $50 \mathrm{mM}$ Tris$\mathrm{HCl}, 70 \mathrm{mM} \mathrm{KCl}, 8 \mathrm{mM} \mathrm{MgSO}_{4}, 10 \mathrm{mM}$ ßmercaptoethanol, $\mathrm{pH}$ 7.5. The extraction medium for glutaminase was $150 \mathrm{mM}$ phosphate buffer (equimolar $\mathrm{K}_{2} \mathrm{HPO}_{4}: \mathrm{KH}_{2} \mathrm{PO}_{4}$ ), $1 \mathrm{mM}$ EDTA and $5 \mathrm{mM}$ Tris-aminomethane, $\mathrm{pH}$ 8.6. HK activity was determined by the method of Uyeda and Racker (13), PFK-1 by the method of Mansour, modified (14), and PHI (15), aldolase (16), PK (17), LDH (18), and glutaminase (19) by previously published methods. All enzymatic analyses were performed by continuous coupled-enzyme spectrophotometric assays and were monitored at $340 \mathrm{~nm}$ and $30^{\circ} \mathrm{C}$ in $1.0-\mathrm{ml}$ volumes. The results are reported as U/mg protein for glycolytic enzymes and as $\mu \mathrm{mol} / \mathrm{min}$ per $\mathrm{g}$ fresh tissue for glutaminase. Tissue protein content was determined by the method of Lowry et al. (20). Data were analyzed statistically by the two-tailed Student $t$-test, with the level of significance set at $\mathrm{P}<0.05$.

The body weight and fresh weights of thymus and mesenteric lymph nodes, reported as the mean \pm SEM of 9 rats, were $320.0 \pm 28.5,0.30 \pm 0.05$, and $0.40 \pm 0.04 \mathrm{~g}$, respectively, for control rats, and $66.0 \pm$ $17.8,0.04 \pm 0.01$, and $0.10 \pm 0.02 \mathrm{~g}$, respectively, for malnourished rats. There was a significant decrease $(\mathrm{P}<0.05)$ in the three parameters due to protein malnutrition. Plasma albumin levels ( $3.70 \pm 0.34$ and 6.60 $\pm 0.78 \mathrm{~g} / 100 \mathrm{ml}$ for malnourished and control rats, respectively, as the mean \pm SEM of 7 determinations) were also reduced $(\mathrm{P}<0.05)$. The decrease in plasma albumin levels (44\%) and in body weight (80\%) indicates the severity of the protein malnutrition schedule imposed on the rats. The fresh weight of the thymus and mesenteric lymph nodes was decreased by $87 \%$ and $75 \%$, respectively. The reduction in lymphoid organ weight has also been reported by others for both laboratory animals and humans (2). The relative weight ( $\mathrm{g} / 100 \mathrm{~g}$ body weight) of the thymus did not differ between groups, whereas a reduction was found for mesenteric lymph nodes $(0.23 \pm 0.05$ compared to $0.10 \pm 0.016$ for control animals, as the mean \pm SEM of 9 rats).

The protein content of the lymphoid organs was also determined. The values (in $\mathrm{mg} / \mathrm{g}$ fresh tissue) expressed as mean $\pm \mathrm{SEM}$ of 5 rats were: for mesenteric lymph nodes, $96.1 \pm 5.2$ (control) and $81.4 \pm 5.7$ (malnourished rats); for thymus, $102.3 \pm 4.4$ (control) and $72.6 \pm 6.6$ (malnourished rats). The reduction in protein content was significant $(\mathrm{P}<0.05)$ only for the thymus.

The activity of the enzymes of the glycolytic pathway was not affected by malnutrition (Table 2). These findings support the proposition that this condition does not seem to affect glucose metabolism of the lymphoid organs and thus a reduction of the flux of metabolites through this pathway is un-

Table 2 - Effect of protein malnutrition on glycolytic enzymes and phosphate-dependent glutaminase activity of immune tissues.

Results of glycolytic enzymes are expressed as $\mathrm{U} / \mathrm{mg}$ protein and of phosphate-dependent glutaminase as $\mu \mathrm{mol} / \mathrm{min}$ per $\mathrm{g}$ fresh tissue. Data are reported as means \pm SEM for 6 rats. ${ }^{*} \mathrm{P}<0.05$ compared to control group as indicated by the Student t-test. HK, Hexokinase; PHI, phosphohexoseisomerase; PFK-1, phosphofructokinase-1; PK, pyruvate kinase; FBP, fructose 1,6bisphosphate; LDH, lactate dehydrogenase.

\begin{tabular}{lcc}
\hline Enzymes & Control & Malnourished \\
\hline Thymus & & \\
Glutaminase & $4.20 \pm 0.40$ & $2.42 \pm 0.20^{*}$ \\
HK & $0.13 \pm 0.03$ & $0.15 \pm 0.03$ \\
PHI & $8.50 \pm 1.70$ & $9.40 \pm 1.40$ \\
PFK-1 & $0.25 \pm 0.04$ & $0.30 \pm 0.05$ \\
Aldolase & $0.28 \pm 0.04$ & $0.31 \pm 0.05$ \\
PK & $2.30 \pm 0.34$ & $2.55 \pm 0.35$ \\
PK plus FBP & $3.60 \pm 0.60$ & $4.12 \pm 0.60$ \\
LDH & $9.40 \pm 1.40$ & $10.90 \pm 1.50$ \\
Mesenteric lymph nodes & & \\
Glutaminase & $4.30 \pm 0.40$ & $2.65 \pm 0.29 *$ \\
HK & $0.14 \pm 0.02$ & $0.17 \pm 0.02$ \\
PHI & $9.60 \pm 1.27$ & $9.28 \pm 1.40$ \\
PFK-1 & $0.22 \pm 0.03$ & $0.23 \pm 0.03$ \\
Aldolase & $0.25 \pm 0.04$ & $0.29 \pm 0.02$ \\
PK & $2.35 \pm 0.38$ & $2.70 \pm 0.41$ \\
PK plus FBP & $3.15 \pm 0.42$ & $3.87 \pm 0.60$ \\
LDH & $9.80 \pm 1.45$ & $9.95 \pm 1.50$ \\
& &
\end{tabular}


likely to play a role in the involution of these organs in protein-malnourished rats.

The glutaminase activity $(\mu \mathrm{mol} / \mathrm{min}$ per $\mathrm{g}$ fresh tissue) of thymus and lymph nodes was reduced by half in malnourished rats as compared to controls (Table 2). These results support the proposition that the flux of substrates through glutaminolysis might be decreased due to protein-calorie malnutrition. Since glutamine is an important precursor of nucleotide synthesis (7), the utiliza- tion of this metabolite is assumed to control the rate of cell proliferation (5). Therefore, a low glutaminase activity may lead to a decrease in the cellularity of the organ and thus of its size and weight.

\section{Acknowledgments}

The authors are indebted to Profs. Lor Cury and Marilene G. Vecchia for their contribution to the formulation of the diets.

\section{References}

1. Gross RL \& Newberne PM (1980). Role of nutrition in immunologic function. Physiological Reviews, 60: 188-302.

2. Chandra RK (1991). Nutrition and immunity: lessons from the past and new insights into the future. American Journal of Clinical Nutrition, 53: 1087-1101.

3. Victora CG, Barros FC, Kirkwood BR \& Vaughan JP (1990). Pneumonia, diarrhea, and growth in the first $4 \mathrm{y}$ of life: a longitudinal study of 5914 urban Brazilian children. American Journal of Clinical Nutrition, 52: 391-396.

4. Werner MC, Costa Rosa LFBP, Romaldini JH \& Curi R (1996). Metabolism of glucose and glutamine in lymphocytes from Graves' hyperthyroid patients: influence of methimazole treatment. Cell Biochemistry and Function, 14: 97-104.

5. Newsholme EA, Newsholme P, Curi R, Challoner MA \& Ardawi MSM (1988). A role for muscle in the immune system and its importance in surgery, trauma, sepsis and burns. Nutrition, 4: 261-268.

6. Serrano MAR, Curi R, Parry-Billings $M$, Williams JF \& Newsholme EA (1993). Effects of glucocorticoids on lymphocyte metabolism. American Journal of Physiology, 264: E24-E28.

7. Curi R \& Newsholme EA (1989). The effect of adenine nucleotides on the rate and fate of glutamine utilisation by incubated mitochondria isolated from rat mesenteric lymph nodes. Molecular and Cellular Biochemistry, 86: 71-76.
8. Curi R, Williams JF \& Newsholme EA (1989). Pyruvate metabolism by lymphocytes: evidence for an additional ketogenic tissue. Biochemistry International, 19: 755-767.

9. Mello MAR \& Cury L (1989). Effects of protein-calorie malnutrition on reproductive performance of young and mature rats. Growth, Development, and Aging, 53: 141-144.

10. Mello MAR \& Cury L (1989). Effects of protein-calorie malnutrition on endocrine pancreatic function in young pregnant rats. Brazilian Journal of Medical and Biological Research, 22: 791-794.

11. Mello MAR \& Luciano E (1995). Effects of protein malnutrition on glucose tolerance in rats with alloxan-induced diabetes. Brazilian Journal of Medical and Biological Research, 28: 467-470.

12. Gornall AG, Bardawill CJ \& David MM (1949). Determination of serum proteins by means of the biuret reaction. Journal of Biological Chemistry, 177: 751-766.

13. Uyeda K \& Racker E (1965). Regulatory mechanisms in carbohydrate metabolism (hexokinase and phosphofructokinase). Journal of Biological Chemistry, 240: 4682-4688.

14. Mansour TE (1963). Studies on heart phosphofructokinase: purification, inhibition, and activation. Journal of Biological Chemistry, 238: 2285-2292.
15. Noltman EA (1966). Phosphoglucose isomerase. Methods in Enzymology, 9: 557-565.

16. Blostein R \& Rutter WJ (1963). Comparative studies of liver and muscle aldolase. Journal of Biological Chemistry, 238: 3280-3285

17. Büchner T \& Pfleider G (1955). Phosphoglycerate kinase from Brower's yeast. Methods in Enzymology, 1: 415-422.

18. Bergmeyer HU \& Bernt E (1974). Lactate dehydrogenase UV-assay with pyruvate kinase and NADH. In: Bergmeyer HU (Editor), Methods of Enzymatic Analysis. 2nd edn. Vol. 2. Academic Press, New York, 574-579.

19. Curthoys NP \& Lowry OH (1973). The distribution of glutaminase isoenzymes in the various structures of the nephron in normal, acidotic and alkalotic rat kidney. Journal of Biological Chemistry, 248: 162168.

20. Lowry OH, Rosebrough NJ, Farr L \& Randall R (1951). Protein measurement with the folin phenol reagent. Journal of Biological Chemistry, 193: 265-275. 